\title{
Investment Specific Technological Progress and Structural Change ${ }^{\star}$
}

\author{
- Ricardo Silva Azevedo Araujo* \\ - Joanílio Rodolpho Teixeira**
}

\begin{abstract}
Resumo
Neste artigo, estendemos o modelo Pasinettiano de mudança estrutural e crescimento econômico para levar em consideração a possibilidade de o progresso tecnológico estar incorporado nos bens de capital. Nosso objetivo consiste em estudar os efeitos do progresso tecnológico investimento específico sobre a mudança estrutural, com especial ênfase nos seus impactos sobre variáveis macroeconômicas como o nível de emprego. Nossos achados mostram que, apesar de esse tipo de progresso tecnológico aumentar a produtividade dos bens de capital, ele impacta negativamente o nível de emprego e as condições de equilíbrio da economia.
\end{abstract}

\section{Palavras-Chave}

dinâmica de mudança estrutural, progresso tecnológico investimento específico, acumulação de capital

\begin{abstract}
In this paper we introduce investment specific technical progress into Pasinetti's model of structural change. Our aim is to assess the effects of embodied technical progress on economic growth and macroeconomic variables. Our findings suggest that despite the fact that this type of technical progress increases the productivity of capital, it has negative effects on conditions that promote full employment.
\end{abstract}

\section{Keywords}

structural economic dynamics, investment specific technical progress, capital accumulation

\section{JEL Classification}

$\mathrm{O} 19, \mathrm{~F} 12$

\footnotetext{
+ We would like to thank the helpful comments of an anonymous referee. The usual disclaimer applies. Financial support from the CNPq is acknowledged.

* Departamento de Economia da Universidade de Brasília (UnB). E-mail: rsaaraujo@unb.br.

** Departamento de Economia da Universidade de Brasília (UnB). E-mail: joanilioteixeira@hotmail.com. Contact address: Campus Universitário Darcy Ribeiro, Brasília, DF. CEP: 70910-900.

(Recebido em setembro de 2009. Aceito para publicação em junho de 2010).
} 


\section{Introduction}

The aim of this paper is to introduce technical progress investment specific in the Pasinetti's model of structural change. The original version of the model contemplates only disembodied technical progress. With the idea to advance Economic Science, we are motivated to investigate how the introduction of embodied technical progress in capital goods affects structural change. For embodied technological progress we understand the development of new types or vintages of capital representing phenomena such as advances in computer technology, and more efficient means of telecommunications, and so on. Given the sector-specific nature of this type of technological change, the Pasinetti's multi-sector model of economic growth and structural change is suitable to study the effects of this kind of technological progress not only on economic growth but also on macroeconomic variables such as the employment level.

The hypothesis that technical progress and capital accumulation cannot be dissociated is raised by Kaldor (1957) through his formulation of a function of technological progress. According to him it is impossible to dissociate technological progress and capital accumulation since the process of capital deepening is always associated with some embodiment of new technologies into new capital goods. Findings advanced by Solow $(1957,1962)$ also suggests that a sizeable portion of technical progress is specific to capital goods but he seems to have abandoned this hypothesis in favour of a more tractable approach, that became widely known as the neoclassical growth model (SOLOW, 1956).

However since Solow's contribution, a number of authors have emphasized complementarities between technical change and investment. Nelson (1964, p. 583), for example, assumes "(...) that total-factor-productivity growth is the result of design technical change that needs to embodied, and hence all of the residual of the simple Cobb-Douglas model really is the result of the failure of the model to take into account improved capital quality". He has found that the variation in the U.S. growth rates is explained by different rates of growth of capital and labour and different trends in the average age of capital. Phelps (1962) have built a growth model that accommodates two types of technical progress and have found that the long-run growth rate depends on the rate of technical progress but not the type of progress. 
More recently, research of Greenwood et al. (1997) suggests that about 60\% of U.S. output growth could be explained by investment specific technological change, attributing the remaining $40 \%$ to Hicks-neutral technical progress. Research of Iglesias (2002) and Licandro et al. ${ }^{1}$ (2002) support similar findings, while also suggesting that the rate of investment specific technical progress has raised and the rate of neutral technical progress decreased after 1974. By performing similar tests on Canada's economy, Kosempel and Carlaw (2003) find that investment specific technological progress accounts for about fifty percent of the growth in the Canadian GDP over the time period 1961-96. When considering the period 1974 to 1996, then the contribution of rate of investment specific technical progress accounts for nearly one hundred percent.

In addition, the advent of what is frequently termed the 'New Economy', understood as that part of an economy exhibiting exponential advances in information process combined with communication technology contributing toward dramatic increases in labour productivity, has served to increase the investment specific nature of technological progress. Research of Boucekkine et al. (2002, p. 76) emphasises: "There has been an acceleration in the rate of embodied technical progress since 1974, corresponding to the rise of the information technologies."

Based upon these noted contributions, one line of theoretical investigation pursued by many scholars considers effects of investment specific technical progress on fairly concrete variables, such as per capita income, real wages, and the like. Although investment specific technological progress is a general purpose technology as pointed out by Jorgenson and Stiroh (2000) its extent may be limited to some sectors of the economy as pointed out by Araujo (2009). According to him this happens if the productivity embodied in capital goods grows so fast that even concentrating ICT in some sectors the productivity gains that accrue from it affects the whole economy.

However, often analyses in this vein are conducted within a limited scope that is, considering but one or two sectors, while failing taking into account structural change. Our contribution, in contrast, proves novel as we seek to analyse effects of investment specific technical progress by employing a multi-sector model that allows for measured growth of productivity and demand for each of the sectors considered. Results obtained suggest that despite investment specific technical progress generating positive effects and outcomes on capital accumulation, negative effects are simultaneously registered on levels of employment. It is hoped that as

1 These authors have confirmed this result by finding that the contribution of embodied technical change to per capita US GDP growth increased from about 60\%, found by Greenwood et al. (1997), to about $70 \%$. 
the study of this kind of approach advances such trade-off may well be eliminated. New results will turn out to be useful for dealing with the structural dynamics and the evaluation of multi-sector models for the purpose of economic policy.

This paper has the following structure. In the next section we focus on the capital accumulation conditions in the Pasinetti's Model. Section 3 introduces investment specific technical progress in this model and derives its implications. Section 4 concludes.

\section{The Pasinetti's Model: An Overview}

In order to carry out our analysis, we think it proves useful to first focus on the derivation of the sectoral capital accumulation conditions in Pasinetti's model. We measure capital goods in terms of units of productive capacity, that is, in terms of the quantity of final goods that could be produced by a specific amount of capital goods. By adopting this convention the sectoral equilibrium condition in the Pasinetti's model could be stated as:

$$
K_{i}=X_{i}
$$

where $X_{i}$ is the quantity of final commodity $i$ that is produced in this sector and $K_{i}$ is the quantity of capital goods installed in the final goods' sector. In order to fulfil the dynamic equilibrium similar changes are introduced to sides of equation (1), and these changes through differentiation, yield:

$$
\dot{K}_{i}=\dot{X}_{i}
$$

On the one hand, variation in the stock of capital goods $i$ when depreciation is not considered, is given by the investment in sector $i$, which is denoted by $x_{k i, n}$. In terms of per capita investment coefficient, $a_{k i, n}$, this equality could be written as follows:

$$
\dot{K}_{i}=x_{k_{i} n}=a_{k_{i} n} X_{n}
$$

Where $X_{n}$ stands for the available labour force. The amount produced of commodity $i$ is thus given by:

$$
X_{i}=a_{i n} X_{n}
$$


The dynamic path of the per capita demand coefficient for commodity $i$ is given by:

$$
a_{i n}(t)=a_{i n}(0) e^{r_{i} t}
$$

where $r_{i}$ determines the growth rate of demand for commodity $i$. The available labour force grows at rate ' $g$ ', yielding the following expression for this variable:

$$
X_{n}(t)=X_{n}(0) e^{g t}
$$

Hence the variation in the quantity produced of commodity $i$ is given by the differentiation of (4), taking into account (5) and (6), which yields:

$$
\dot{X}_{i}=\left(r_{i}+g\right) X_{i}
$$

By equalizing (3) to (4) we then obtain the sectoral condition of capital accumulation:

$$
a_{k_{i} n}=\left(r_{i}+g\right) a_{i n}
$$

If this condition is fulfilled in each sector, then the amount of capital goods required to endow the labour force with the equipment to produce the demanded amount of final good $i$ would be available in every period. The characterization of the equilibrium could then be completed by introducing the effective demand condition, which is given by:

$$
\sum_{i=1}^{n-1} a_{i n}(t) a_{n i}(t)+\sum_{i=1}^{n-1} a_{n k_{i}}(t) a_{k_{i} n}(t)=1
$$

The production coefficients of consumption and capital goods are respectively $a_{n i}$ and $a_{n k i}$. Pasinetti (1981) shows that the fulfilment of expression (9) guarantees full employment of the labour force and full expenditure of national income. In what follows we shall consider the following dynamic paths for technical coefficients:

$$
\begin{aligned}
& a_{n i}(t)=a_{n i}(0) e^{-\rho_{i} t} \\
& a_{n k_{i}}(t)=a_{n k_{i}}(0) e^{-\rho_{k_{i} t}}
\end{aligned}
$$


where the rate of technical change ${ }^{2}$ for sector $i$ is denoted by $\rho_{i}$ while $\rho_{k i}$ offers the same meaning in relation to sector $k_{i}$. By considering that our effective demand condition is fulfilled in the first time, Pasinetti shows that in general it will not necessarily be fulfilled later on, related to the existence of particular growth rates of demand and productivity in each of the model's sectors.

\section{Investment Specific Technical Progress}

We shall then propose two possible ways for introducing investment specific technological progress in Pasinetti's model of structural change. Let us start by the simplest one, what is derived through a sectoral equation of investment along lines suggested by Greenwood et al. (1987). In this case expression (3) has to be replaced by:

$$
\dot{K}_{i}=\sigma_{i} x_{k i, n}=\sigma_{i} a_{k i, n} X_{n}
$$

where $\sigma_{i}>1$ captures the investment specific technological progress. As $\dot{X}_{i}=a_{i n} r_{i} X_{n}+a_{i n} X_{n} g \Rightarrow \dot{X}_{i}=\left(r_{i}+g\right) a_{i n} X_{n}$ and the equilibrium requires that $\dot{K}_{i}=\dot{X}_{i}$, so, it follows that:

$$
a_{k i, n}=\left(\frac{r_{i}+g}{\sigma_{i}}\right) a_{i n}
$$

By taking the derivative of (12) in relation to $\sigma_{i}$ yields:

$$
\frac{\partial a_{k i, n}}{\partial \sigma_{i}}=-\left(\frac{r_{i}+g}{\sigma_{i}^{2}}\right) a_{i n}<0
$$

In this case the capital accumulation condition proves even less restrictive than in the case lacking in investment specific technological progress. Such a result arises related to the fact that the coefficient of investment per capita required to fulfil the demand requirements registers as smaller as the higher is the rate of investment specific technical progress. This result shows that sectoral capital accumulation is smaller than in the case without embodied technical progress since less capital goods is required to fulfil the demand requirement. Another possibility for tackling

2 See Reati (1998) for a more complex dynamics of prices, output and employment level in the Pasinetti's model that considers technological progress according to long waves. 
investment specific technological progress involves considering variation in the stock of capital of sector $i$, what is given by the following expression:

$$
\dot{K}_{i}=x_{k i, n}(t) e^{-\left(\delta_{i}-\theta_{i}\right) t}
$$

where $x_{k i, n}(t)$ represents investment in sector $i$ made in period $t$. It is assumed that this investment embodies a rate of technical progress given by $\theta_{i}$ and depreciates at rate $\delta_{i}$. By integrating both sides (of equation (14)) we conclude that the amount of capital stock in period $\mathrm{t}$ in sector $i$ is given by:

$$
K_{i}(t)=\int_{0}^{t} x_{k_{i} n}(v) e^{-\left(\delta_{i}-\theta_{i}\right) v} d v
$$

This approach is also the one adopted by Solow (1957) and followed by other authors such as Phelps (1962) and Nelson (1964). These contributions assume that capital vintages embodied higher levels of technical progress. This is also incorporated in Pasinetti's model, through assuming that the stock of capital goods in sector $i$ in time $t$ embodies technical progress that grows at a rate $\theta_{i}$ and depreciates at rate $\delta_{i}$. Then the stock of capital goods in sector $i$ is given by the integral of the past vintages of capital goods which embodies higher levels of technical progress and depreciates at the same rate. However, from expression (3) we know that $x_{k_{i} n}=a_{k_{i} n} X_{n}$ and, by substituting this result into expression (14), that is by equalizing $x_{k i, n}(t) e^{-\left(\delta_{i}-\theta_{i}\right) t}$ to $\left(r_{i}+g\right) a_{i n} X_{n}$ yields:

$$
a_{k i, n}=\left(\frac{r_{i}+g}{e^{-\left(\delta_{i}-\theta_{i}\right) t}}\right) a_{i n}
$$

This equation (18) presents the capital accumulation condition. If we make:

$$
\sigma_{i}(t)=e^{-\left(\delta_{i}-\theta_{i}\right) t}
$$

Then $\sigma_{i}$ would register as a net rate of investment specific technical progress. In addition, equation (16) could be posed as:

$$
a_{k i, n}=\left(\frac{r_{i}+g}{\sigma_{i}(t)}\right) a_{i n}
$$


It is important to consider that equation (12) appears as particular solution of (18) when $\sigma_{i}(t)$ is constant through time. In order to evaluate the impact of investment specific technological progress in the employment level, let us then substitute expression (18) into expression (7). By substituting the capital accumulation condition into the employment condition we obtain:

$$
E L(t)=\sum_{i=1}^{n-1} a_{i n} a_{n i}+\sum_{i=1}^{n-1}\left\{\left(\frac{r_{i}+g}{\sigma_{i}}\right) a_{i n}\right\} a_{n k i}
$$

By taking the derivative of the employment level $(E L)$ in relation to $\sigma_{i}$, this allows us to conclude that it may be smaller due to the absorption of technical progress.

$$
\frac{\partial E L(t)}{\partial \sigma_{i}}=-\sum_{i=1}^{n-1}\left\{\left(\frac{r_{i}+g}{\sigma_{i}^{2}}\right) a_{i n}\right\} a_{n k i}<0
$$

Expression (20) suggests that the higher the rate of sectoral investment specific technical progress the smaller the employment level. Stated somewhat differently, embodied technical progress, likely the conventional technical progress, exhibits negative effects on levels of employment. Let us now evaluate effects of embodied technological progress on the accumulation of capital. From expression (15) we know that:

$$
K_{i}(t)=\int_{0}^{t} a_{k_{i} n}(v) X_{n}(v) e^{-\left(\delta_{i}-\sigma_{i}\right) v} d v
$$

Since we have the investment allocation condition given by (18), let us then substitute it into expression (21), obtaining:

$$
K_{i}(t)=\int_{0}^{t}\left(\frac{g+r_{i}}{e^{-\left(\delta_{i}-\theta_{i}\right) t}}\right) a_{i n}(0) X_{n}(0) e^{\left(g+r_{i}-\delta_{i}+\theta_{i}\right) v} d v
$$

This yields after solving this integral:

$$
K_{i}(t)=a_{i n}(0) X_{n}(0)\left[e^{\left(r_{i}+g\right) t}-1\right]
$$

The growth rate of the stock of capital goods in sector $i$ is given by: 


$$
\frac{\dot{K}_{i}}{K_{i}}=\frac{\left(r_{i}+g\right) e^{\left(g+r_{i}\right) t}}{-1+e^{\left(g+r_{i}\right) t}}
$$

If we consider this growth rate when $t \rightarrow \infty$ we find an indetermination since both numerator and denominator tends toward infinity. By applying L'Hôspital's rule we conclude that:

$$
\lim _{t \rightarrow \infty} \frac{\dot{K}_{i}}{K_{i}}=r_{i}+g
$$

In other words, over the long run, investment specific technical progress fails to affect the rate of growth of stock of capital goods in sector $i$. This result suggests that our formulation proves consistent with the long run growth path of the model, since the growth rate of production of consumption goods is given by:

$$
\frac{\dot{X}_{i}}{X_{i}}=g+r_{i}
$$

Important to consider is that if these two rates differ, the model would not prove useful for predicting the long run evolution of sectors in which $\sigma_{i}>\delta_{i}$ or $\sigma_{i}<\delta_{i}$. In order to assess the importance of the investment specific technical progress, it proves important to judge whether resulting structural changes that accrue are limited to just a few sectors, or are actually widespread throughout a modelled economy. For some authors, such as Gordon (2000, p. 72), the "New Information Economy" created a dynamic explosion of productivity growth in the durable manufacturing sector.

However, this it has generated minimal effects on about 88 percent of economic activity, what remains outside durable manufacturing. Research of Jorgenson and Stiroh's (2000) dispute this view by considering that the Technology of Information and Communication emerges as a general purpose technology, increasing productivity throughout sectors and industries composing the U.S. economy. The latter view seems to be the correct one and shows that the structural change that result from investment specific technological progress cannot be disregarded, remaining important for economists to consider. 


\section{Concluding Remarks}

In this paper we have introduced investment specific technological progress in the Pasinetti's model of Structural Change and have analyzed its effects on economic growth and on macroeconomic variables such as the employment level. The line of research that measures not only the participation of investment specific technological progress on economic growth but also its impacts on macroeconomic variables have been pursued by a number of authors. ${ }^{3}$ They emphasize that the bias of technological progress has changed in the nineties from a labour saving technological progress - Harrod Neutral - to an investment specific technological progress - Hicks Neutral. In this vein they have confirmed Kaldor's view that capital deepening is also related to the embodiment hypothesis.

Here we contemplate this possibility by adopting a Structural Economic Dynamic approach to study the effects of the embodiment hypothesis. It is found that the investment specific technological progress does not affect directly technical coefficients but it affects the employment level through another channel - the sectoral investment conditions. Despite the fact that this types of technical progress increases productivity of capital it also generates negative impacts on the employment level. In this vein the Hicks neutral technological progress continues to present the same effect of the traditional Harrod-neutral specification and economic policies that aim to alleviate the impacts of technological progress in the labour market should be considered.

\section{References}

ACEMOGLU, D. Technical change, inequality, and the labour market. Journal of Economic Literature XL, p. 7-72, 2002.

ARAUJO, R. Optimal investment specific technological progress allocation in a two sector model. Revista Economia (Anpec), v. 10, n. 3, p. 457-464, 2009.

ARAUJO, R.; TEIXEIRA, J. An extension of the structural change model to international economic relations. Metroeconomica, v. 54, p. 458-473, 2003.

. Structural Economic Dynamics: An Alternative Approach to North-South Models, Cambridge Journal of Economics, v. 28, p. 705 - 717, 2004.

BOUCEKKINE, R.; DE LA CROIX, D.; VAILAKIS, Y. Technological shocks and IT revolutions. Louvain Economic Review, v. 68, p. 75-89, 2002.

GORDON, R. Does the 'new economy' measure up to the great inventions of the past? Journal of Economic Perspectives, v. 14, p. 49-74, 2000.

3 See Greenwood et al. (2000) and Acemoglu (2002). 
The role of investment specific technological change in the business cycle. European Economic Review 44, p. 91-115, 2000.

GREENWOOD, J.; HERCOWITZ, Z.; KRUSELL, P. Long-run implications of investment-specific technological change. The American Economic Review, v. 87, n. 3, p. 342- 362, 1997.

IGLESIAS, F. Neutral, investment-specific technical progress and the productivity slowdown. Louvain Economic Review, v. 68, p. 37-49, 2002.

JORGENSON D.; STIROH, K. Raising the speed limit: U.S. economic growth in the information age. Brooking Papers on Economic Activity, I, p. 125-235, 2000.

KALDOR, N. A Model of Economic Growth. The Economic Journal, v. 67, p. 591624, 1957.

KOSEMPEL, S.; CARLAW, K. Accounting for Canada's economic growth. Journal of Economic Development, v. 28, p. 83-101, 2003.

LICANDRO, O.; CASTILLO, J.; DURÁN, J. The measurement of growth under embodied technical change. Louvain Economic Review, v. 68, p. 7-20, 2002.

NELSON, R. Aggregate production functions and medium-range growth projections. American Economic Review, v. 54, n. 5, p. 575-606, 1964.

PASINETTI, L. Structural change and economic growth - a theoretical essay on the dynamics of the wealth of the nations. Cambridge, UK: Cambridge University Press, 1981.

Structural economic dynamics - a theory of the economic consequences of human learning. Cambridge, UK: Cambridge University Press, 1993.

PHELPS, E. The new view of investment: a neoclassical analysis. The Quarterly Journal of Economics, v. 76, n. 4, p. 548-567, 1962.

REATI, A. Technological revolutions in Pasinetti's model of structural change: productivity and prices. Structural Change and Economic Dynamics, v. 9, n. 2, p. 245-262, 1998.

SOLOW, R. A contribution to the theory of economic growth. Quarterly Journal of Economics, v. 70, p. 65-94, 1956.

. Technical change and the aggregate production function. Review of Economics and Statistics, v. 39, 312-320, 1957.

. Technical progress, capital formation and economic growth. The American Economic Review, v. 52, p. 76-86, 1962. 